REPORT ON THE CANADIAN JOURNAL OF MATHEMATICS (1956-1957)

Finance. Grants to support the Journal were recelved as follows:

\begin{tabular}{lr} 
National Research Council & \\
American Mathematical Society & 5,000 \\
University of Alberta & 900 \\
Assumption University & 200 \\
University of British Columb1a & 50 \\
Carleton University & 250 \\
Dalhousie University & 50 \\
Ecole Polytechnique & 100 \\
Universite Laval & 50 \\
Loyola College & 50 \\
University of Manitoba & 35 \\
McGili University & 100 \\
McMaster University & 250 \\
University of Montreal & 100 \\
Queen's University & 50 \\
Royal Military Coliege and Royal Roads & 100 \\
St.Mary's University & 100 \\
University of Toronto & 25 \\
& 1,500 \\
\hline
\end{tabular}

In addition, $\$ 5,530$ was recelved from subscriptions, advertising, reprints, etc. Total cost of printing (at the University of Totonto Press) was about \$12,500, leaving, after other expenses, a balance of $\$ 5,700$.

The Editors express their thanks to the above contributors, and also to the press for editorial assistance.

Circulation. The number of library subscriptions has increased to 582, while individual subscriptions have dropped slightiy to 223 . The total circulation of 823 (including complimentary copies) was divided among many countries, as follows:

$\begin{array}{lrlr}\text { Canada } & 119 & \text { Russia } & 22 \\ \text { U.S. A. } & 301 & \text { China } & 64 \\ \text { U.K. } & 51 & \text { Japan } & 38 \\ \text { (and Ireland) } & & \text { India } & 21 \\ \text { France } & 21 & \text { Others } & 133 \\ \text { Italy } & 28 & & \\ \text { Germany } & 25 & & 823\end{array}$

The large number of subscriptions from China is due to a single Government order. 
Editorial Remarks. The number of pages published in 1957 was $624,42 \%$ by Canadians or former Canadians. This compares with $34 \%$ in 1956 , and probably reflects the influence of the Summer Research Institute.

Professor G. F. D. Duff will take over as Editorin-Chief at the end of the current volume. The Editors wish him every success, and extend their thanks to all who have given editorial assistance or refereed papers.

$$
\begin{aligned}
& \text { H. S. M. Coxeter } \\
& \text { G. de B. Robinson }
\end{aligned}
$$

\section{THE CANADIAN MATHEMATICAL CONGRESS SEMINAR IN EDMONTON}

\section{August 12 to August 31, 1957}

The sixth mathematics seminar was held on the University of Alberta campus in Edmonton, Alberta, in conJunction with the first seminar of the Canadian Association of Physicists (Theoretical Physics Division). The following courses were given:

Instructional Lectures in Mathematics Theory of Numbers, L. Moser Introduction to Mathematical Logic, A. Robinson Theory of Games and Linear Programming, A. W. Tucker Introduction to Theory of Lie Rings, H. J. Zassenhaus

Instructional Iectures in Theoretical Physics High Energy Physics, J. D. Jackson Some Aspects of the Theory of Magnet1sm, W.Opechowski Quantum Theory of Angular Momentum, W. T. Sharp Scattering Theory, T. Y. Wu

Research Lectures in Mathematics Intrinsic Geometry of General Surfaces, A.D.Alexandrov

Les Anneaux d'opérateurs, J. Dixmier (Paris) (Leningrad) Nilpotent Groups, Philip Hall (Cambridge) Quantum Mechanics and Relativistic Invariance, E.P. Wigner (Princeton)

Research Lectures in Theoretical Physics Solid State Theory, E.N. Adams (Westinghouse) Some Properties of Uncommon Forms of Matter, P. Morrison (Cornell)

Fundamental Particles and their Interactions, J. Schwinger (Harvard) 